\title{
ARTICLE
}

\section{A Simple Method for Simultaneous Determination of Commonly used Artificial Food Colors and Preservatives in Soda, Jam, and Yogurt by HPLC-PDA}

\author{
Ahlam S. Al-Kharosi ${ }^{1}$, Waleed A. Al-Sabari ${ }^{1}$, Faisal H. AL-shidhani ${ }^{1}$, Sohrab A. Alfarsi ${ }^{1}$, \\ Sherif M. Taha2* iD $ه$ \\ ${ }^{1}$ Muscat municipality laboratory, Directorate general of health affairs, Postal code: 115 , Sultanate of Oman \\ ${ }^{2}$ Agriculture Research Centre, Central Laboratory of Residue Analysis of Pesticides and Heavy Metals in Foods \\ (QCAP), 7 Nadi El Said st., Dokki, Giza, Egypt
}

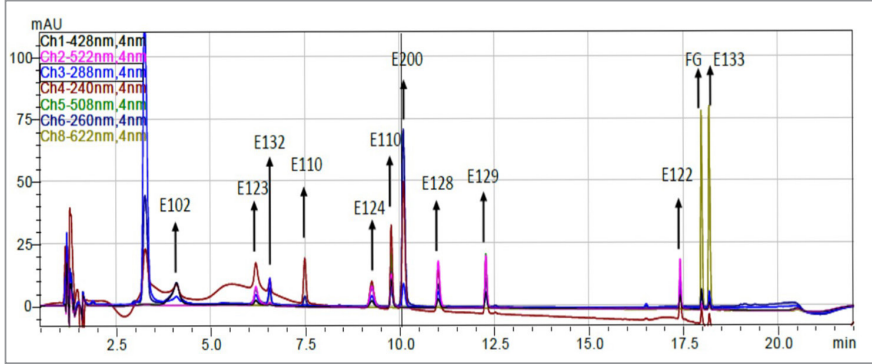

In this study, a simple and sensitive analytical method for the analysis of an expanded scope of food additives in three different matrices using HPLC-PDA was developed. This method was validated for the simultaneous analysis of the commonly used ten food colors and two preservatives of different polarities and chemical structures. The studied matrices included: soda juice, jam, and yogurt. The mixture of $\mathrm{H}_{2} \mathrm{O}: \mathrm{MeOH}$ $(1: 3, v: v)$ with $0.01 \mathrm{~mol} \mathrm{~L}^{-1} \mathrm{NaOH}$ allowed low limits of quantifications (LOQ) for most of the studied food additives. Acceptable recoveries within the range $60-100 \%$ with an associated precision (RSD) $<20 \%$ were obtained for all the studied food additives at a low concentration of $1.00 \mathrm{mg} \mathrm{kg}^{-1}$ in jam and yogurt except tartrazine and benzoic acid which could be determined at concentrations of $5.00 \mathrm{mg} \mathrm{kg}^{-1}$ in jam and equal to 5.00 and $10.00 \mathrm{mg} \mathrm{kg}^{-1}$ in yogurt, respectively. The studied food additives could also be determined at lower concentrations in soda juice samples, as analyzed with a lower dilution factor. A complete separation for the tested additives was achieved at run time of 22 min using a mobile phase consisting of solvent $A$ of $0.10 \mathrm{~mol} \mathrm{~L}^{-1}$ ammonium acetate buffer ( $\left.\mathrm{pH} 4.60\right)$ in a mixture of $\mathrm{H}_{2} \mathrm{O}: \mathrm{MeOH}(95: 5$, v:v) and solvent $\mathrm{B}$ of $\mathrm{ACN}: \mathrm{MeOH}(7: 3, \mathrm{v}: \mathrm{v})$. This method was successfully applied for the analysis of eighteen real samples. The eight collected soda juice samples were found to contain at least one food preservative with one or more food color.

Keywords; Artificial colors, Food preservatives, Soda Juice, Jam, Yogurt, HPLC-PDA

\section{INTRODUCTION}

Artificial food colors are usually used to add more purchasing values to the foodstuff and juices especially that of children's interest. The main reasons for the increment usage of such synthetic colors 
are attributed to its high stability and being of a lower price when compared to natural colors [1]. However, overuse concentrations from these artificial colors may lead to frequent headaches for adults and increase children's hyperactivity [2]. Azo dyes may be transformed under specific conditions to form genotoxic and carcinogenic products [3,4]. Benzoic acid and sorbic acid are the most commonly used food preservatives that prevent deterioration of foodstuffs caused by microbial contamination [5-7]. Therefore, there is a high probability of finding one or more colors together with benzoic and/or sorbic acid in the same sample. Although liquid chromatography-tandem mass spectrometry technique enables the simultaneous analysis of not well chromatographically separated compounds, only a few papers were published on LC-MS/ MS analysis of a low number of artificial colors in limited matrices [1,8-10]. This is mainly attributed to inefficient extraction methods that enable such multi food additives (FA) analysis in various food matrices. In addition, most of the current extraction methods for the analysis of FA require intensive sample preparation techniques, especially for the determination of artificial colors in high protein content sample, applying Solid Phase Extraction (SPE) clean up [11-15] or many sample preparation steps [16].

In the current paper, a simple and cheap method for the simultaneous analysis of ten food colors and two preservatives in different matrix categories was established using HPLC-PDA. This method was fully validated for soda juice, jam, and yogurt samples according to SANTE/11813/2017 [17].

\section{MATERIAL AND METHODS \\ Chemicals and reagents}

Methanol and a ready prepared $\mathrm{NaOH}$ solution $\left(1 \mathrm{~mol} \mathrm{~L}^{-1}\right)$ were purchased from PROLAB chemicals. Ammonium acetate was obtained from Fischer Scientific. The used deionized water (DIW) of $17 \Omega \mathrm{cm}$ was obtained using Veolia water solutions and Technologies. All the studied food colors were purchased from Sigma Aldrich Inc. Benzoic and sorbic acids were obtained from LRSD Fine-Chem Ltd. and Sisco Research Laboratories, respectively.

\section{Preparation of standard working solutions}

A stock standard solution for each FA standard (Table I) was prepared at a concentration of $1000 \mu \mathrm{g}$ $\mathrm{mL}^{-1}$ in $10 \mathrm{~mL}$ of $\mathrm{H}_{2} \mathrm{O}: \mathrm{MeOH}(1: 3, \mathrm{v}: \mathrm{v})$ for most of the studied FA. A stock standard solution for tartrazine was prepared in $\mathrm{H}_{2} \mathrm{O}: \mathrm{MeOH}(3: 1, \mathrm{v}: \mathrm{v})$, and for Amaranth, Indigo, and Ponceau in $\mathrm{H}_{2} \mathrm{O}: \mathrm{MeOH}(1: 1, \mathrm{v}: \mathrm{v})$. A working standard solution mixture of $25 \mathrm{mg} \mathrm{kg}^{-1}$ for all the studied FA and of $50 \mathrm{mg} \mathrm{kg}^{-1}$ for tartrazine and benzoic acid was prepared by diluting a suitable aliquot of the stock solutions in $\mathrm{H}_{2} \mathrm{O}: \mathrm{MeOH}(1: 3, \mathrm{v}: \mathrm{v})$. This mixture was then stored at $4{ }^{\circ} \mathrm{C}$ and was used for the fortification of the blank samples and the analytical curve preparation.

Table I. Analyzed food additives, respective retention times and wavelengths used for their detection

\begin{tabular}{clccccc}
\hline $\mathbf{N}$ & $\begin{array}{l}\text { Food } \\
\text { Additive }\end{array}$ & Molecular formula & MWt & E number $^{\mathbf{2}}$ & $\mathbf{t}_{\mathrm{R}}$ (min) & $\begin{array}{c}\text { Wavelength } \\
\text { (nm) }\end{array}$ \\
\hline 1 & Tartrazine & $\mathrm{C}_{16} \mathrm{H}_{9} \mathrm{~N}_{4} \mathrm{Na}_{3} \mathrm{O}_{9} \mathrm{~S}_{2}$ & 534.36 & $\mathrm{E} \mathrm{102}$ & 4.06 & 428 \\
2 & Indigo & $\mathrm{C}_{16} \mathrm{H}_{8} \mathrm{Na}_{2} \mathrm{~N}_{2} \mathrm{O}_{8} \mathrm{~S}_{2}$ & 466.36 & $\mathrm{E} \mathrm{132}$ & 6.57 & 289 \\
3 & Benzoic $\mathrm{A}$ & $\mathrm{C}_{7} \mathrm{H}_{6} \mathrm{O}_{2}$ & 122.1 & $\mathrm{E} \mathrm{110-113}$ & 7.49 & 240 \\
4 & Sorbic $\mathrm{A}$ & $\mathrm{C}_{6} \mathrm{H}_{8} \mathrm{O}_{2}$ & 112.12 & $\mathrm{E} \mathrm{200,} \mathrm{202,} \mathrm{203}$ & 10.11 & 240 \\
5 & Amaranth & $\mathrm{C}_{20} \mathrm{H}_{11} \mathrm{~N}_{2} \mathrm{Na}_{3} \mathrm{O}_{10} \mathrm{~S}_{3}$ & 604.49 & $\mathrm{E} \mathrm{123}$ & 6.20 & 518 \\
6 & Ponceau & $\mathrm{C}_{20} \mathrm{H}_{11} \mathrm{~N}_{2} \mathrm{Na}_{3} \mathrm{O}_{10} \mathrm{~S}_{3}$ & 604.48 & $\mathrm{E} \mathrm{124}$ & 9.27 & 518 \\
7 & Sunset $\mathrm{Y}$ & $\mathrm{C}_{16} \mathrm{H}_{10} \mathrm{~N}_{2} \mathrm{Na}_{2} \mathrm{O}_{7} \mathrm{~S}_{2}$ & 452.37 & $\mathrm{E} \mathrm{110}$ & 9.78 & 518 \\
8 & Acid R 33 & $\mathrm{C}_{18} \mathrm{H}_{14} \mathrm{~N}_{2} \mathrm{Na}_{2} \mathrm{O}_{8} \mathrm{~S}_{2}$ & 496.41 & $\mathrm{E} \mathrm{128}$ & 11.02 & 518 \\
9 & Allura R & $\mathrm{C}_{18} \mathrm{H}_{14} \mathrm{~N}_{2} \mathrm{Na}_{2} \mathrm{O}_{8} \mathrm{~S}_{2}$ & 496.43 & $\mathrm{E} \mathrm{129}$ & 12.28 & 518 \\
\hline
\end{tabular}


Table I. Analyzed food additives, respective retention times and wavelengths used for their detection (Cont.)

\begin{tabular}{clccccc}
\hline $\mathbf{N}$ & $\begin{array}{l}\text { Food } \\
\text { Additive }\end{array}$ & Molecular formula & MWt & E number $^{\mathbf{a}}$ & $\mathbf{t}_{\mathrm{R}}$ (min) & $\begin{array}{c}\text { Wavelength } \\
(\mathbf{n m})\end{array}$ \\
\hline 10 & Carmoisine & $\mathrm{C}_{20} \mathrm{H}_{12} \mathrm{~N}_{2} \mathrm{Na}_{2} \mathrm{O}_{7} \mathrm{~S}_{2}$ & 502.44 & $\mathrm{E} \mathrm{122}$ & 17.42 & 518 \\
11 & Fast G & $\mathrm{C}_{37} \mathrm{H}_{34} \mathrm{~N}_{2} \mathrm{Na}_{2} \mathrm{O}_{10} \mathrm{~S}_{3}$ & 808.84 & - & 17.98 & 622 \\
12 & Brilliant B & $\mathrm{C}_{37} \mathrm{H}_{34} \mathrm{~N}_{2} \mathrm{Na}_{2} \mathrm{O}_{9} \mathrm{~S}_{3}$ & 792.85 & $\mathrm{E} \mathrm{133}$ & 18.19 & 622 \\
\hline
\end{tabular}

${ }^{\mathrm{a} C}$ Codes for substances used as food additives within the European Union and European Free Trade Association.

\section{Final extraction method procedure}

One gram of yogurt \& jam and $2 \mathrm{~mL}$ of soda juice (previously sonicated for $2 \mathrm{~h}$ ) samples were weighed into a $10 \mathrm{~mL}$ measuring separating flask. For the recovery experiments, the samples were fortified by adding appropriate volumes of the FA working mixture, which were then left for 15 min with applying vortex per 5 minutes interval times. Ten milliliters of $\mathrm{H}_{2} \mathrm{O}: \mathrm{MeOH}(1: 3, \mathrm{v}: \mathrm{v})$ containing $0.01 \mathrm{~mol} \mathrm{~L}^{-1} \mathrm{NaOH}$ was added to the mark of the used measuring flask. Then, this solution was vortexed, transferred into $15 \mathrm{~mL}$ centrifugation tubes, and shaken by hand for $1 \mathrm{~min}$. Then after, a soda juice extract solution was collected in a vial using an acrodisc syringe filter of $0.45 \mu \mathrm{m}$. While the tubes of jam and yogurt extract solution were centrifuged ( $3700 \mathrm{rpm}$ ) for $5 \mathrm{~min}$ and subsequently collecting the supernatants using acrodisc syringe filter of $0.45 \mu \mathrm{m}$.

\section{HPLC-PDA conditions}

A liquid chromatograph (Nexera LC 2040, Shimadzu, Kyoto, Japan) coupled to UV-Vis detector with a photodiode unit was used for the chromatographic analyses in this study. Chromatographic separation was carried out using a C18 column of small internal diameter and particle size (Restek column, $3.00 \mathrm{~mm}$ $\times 100 \mathrm{~mm} \times 2.7 \mu \mathrm{m})$ at $25^{\circ} \mathrm{C}$ and a sample injection volume of $2 \mu \mathrm{l}$. A fast HPLC runtime of 22 min was developed for the analysis of 12 different FA (10 food colors and 2 food preservatives). The mobile phase components consisted of solvent (A): a mixture of $\mathrm{H}_{2} \mathrm{O}: \mathrm{MeOH}(95: 5, \mathrm{v}: \mathrm{v})$ with $\mathrm{pH} 4.60$ adjusted using ammonium acetate buffer $\left(0.10 \mathrm{~mol} \mathrm{~L}^{-1}\right)$; and solvent (B): a mixture of $\mathrm{ACN}: \mathrm{MeOH}(7: 3, \mathrm{v}: \mathrm{v})$. The mobile phase was pumped at a flow rate of $0.30 \mathrm{~mL} \mathrm{~min}^{-1}$ with an optimized solvent gradient program, as follows: 0-2 min, 3\% solvent B; $2-4$ min, 3-10\% solvent B; $4-14$ min $10-25 \%$ solvent $B ; 14-18$ min $25-60 \%$ solvent $B$; then, the program was held constant at $3 \%$ to the end of the run time 22 min.

\section{Method Validation}

The developed method was fully validated for the analysis of the studied food additives, according to SANTE/11813/2017, in yogurt, jam, and soda juice. For linearity evaluations, six calibration levels were prepared in soda, jam, and yogurt extracts at $0.05,0.10,0.25,0.50$ and $2.50 \mathrm{mg} \mathrm{L}^{-1}$ for all the studied FA except for tartrazine and benzoic acid which were prepared at 0.10, 0.20, 0.50, 1.00, and $5.00 \mathrm{mg} \mathrm{L}^{-1}$.

The intra-day accuracy and precision of the developed method were evaluated at three different concentration levels of $1.00,2.50$, and $5.00 \mathrm{mg} \mathrm{kg}^{-1}$ for all the studied FA, except for tartrazine and benzoic acid whose concentration levels were 2.00, 5.00, and $10.00 \mathrm{mg} \mathrm{kg}^{-1}$, in jam and yogurt. These three concentration levels are corresponding to lower levels of $0.5,1.25$, and $2.5 \mathrm{mg} \mathrm{kg}^{-1}$ for all the studied FA, except for tartrazine and benzoic acid at 1.00, 2.50, and $5.00 \mathrm{mg} \mathrm{kg}^{-1}$, in soda juice, as it has a lower dilution factor.

The inter-day evaluation was carried out within five repeated days, at a concentration level of $5.00 \mathrm{mg}$ $\mathrm{kg}^{-1}$ for most of the studied FA, except for tartrazine and benzoic acid at $10.00 \mathrm{mg} \mathrm{kg}^{-1}$ in jam and yogurt. These experiments were also carried out for soda juice sample at a concentration level of $2.50 \mathrm{mg} \mathrm{kg}^{-1}$ for all of the studied FA, except for tartrazine and benzoic acid at $5.00 \mathrm{mg} \mathrm{kg}^{-1}$. 


\section{RESULTS AND DISCUSSION \\ Development of the food additive analysis method}

The two main goals of this study were to achieve satisfactory peak separations corresponding to the extracted FA, and to develop a unified extraction method for these different FA from the highly different studied matrices.

\section{Optimizing the chromatographic separation}

Different mobile phases and gradient elution were tested to obtain an efficient separation for all the studied FA (Table I). A mixture of $\mathrm{H}_{2} \mathrm{O}: \mathrm{MeOH}(95: 5, \mathrm{v}: \mathrm{v})$ was selected for sample loading on the used RP-column. The presence of organic solvent in the used loading solution is important to prevent algae formation and enhance the evaporation of the mobile phase in case applying this study for ESI-LC-MS/ MS analysis. Ammonium acetate of $0.10 \mathrm{~mol} \mathrm{~L}^{-1}$ was added to the studied loading solution $(\mathrm{pH} \mathrm{4.60)}$ to enable the simultaneous analysis of both food colors and preservatives. Ammonium acetate buffer was selected as it has lower aggressive characters than using phosphate buffer. $\mathrm{ACN}, \mathrm{MeOH}$, and their mixtures at different ratios were tested for the proper elution of the retained FA. A deep focusing was paid on increasing the retaining of the highly polar studied FA, tartrazine, amaranth, and indigo, with obtaining a satisfactory separation between sorbic acid and the moderately polar FA (ponceau, sunset $Y$, acid R, and Allura R) and also proper separation for the late eluted FA (carmoisine, fast $G$, and brilliant $B$ ) without further increasing the overall run time. Therefore, different temperatures $\left(25-40^{\circ} \mathrm{C}\right)$ were also optimized on the used RP-Phase C18 column, of a smaller particle size of $2.7 \mu \mathrm{m}$. The best optimized chromatographic separation conditions were obtained using a loading solvent of $\mathrm{H}_{2} \mathrm{O}: \mathrm{MeOH}(95: 5, \mathrm{v}: \mathrm{v})$, elution solvent of $\mathrm{ACN}: \mathrm{MeOH}(7: 3, \mathrm{v}: \mathrm{v})$, and applying a temperature of $25^{\circ} \mathrm{C}$ for the used column. Details of the elution program are mentioned in Material and Methods item. Figure 1 shows the obtained chromatogram for the analysis of the studied FA in yogurt (dilution factor equal 10), at a concentration of $5 \mu \mathrm{g} \mathrm{kg}^{-1}$ for all of the studied FA, except for tartrazine and benzoic acid at $10.00 \mathrm{mg} \mathrm{kg}^{-1}$.

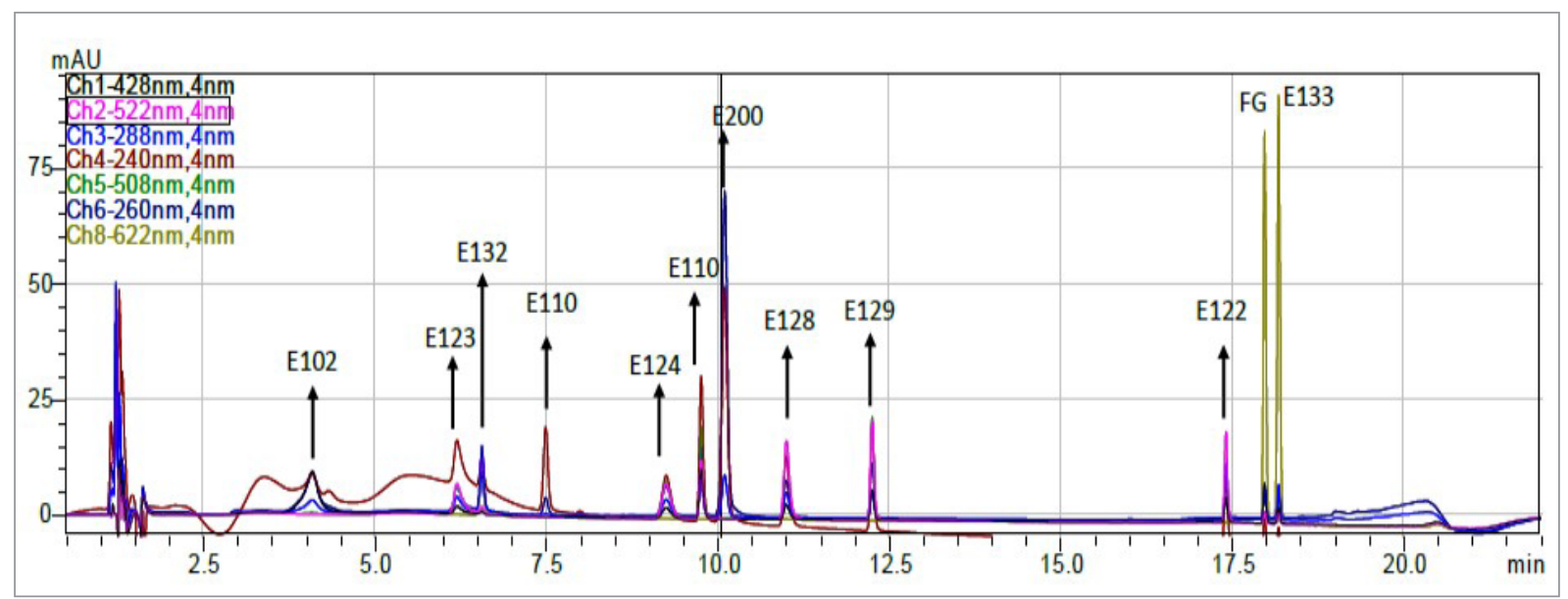

Figure1. HPLC chromatogram of the analyzed food additives mixture solution: Tartrazine (E 102, $10 \mathrm{mg}$ $\mathrm{kg}^{-1}$ ); Amaranth (E 123, $5 \mathrm{mg} \mathrm{kg}^{-1}$ ); Indigo (E 132, $5 \mathrm{mg} \mathrm{kg}^{-1}$ ); Benzoic A (E 110, $10 \mathrm{mg} \mathrm{kg}^{-1}$ ); Ponceau (E 124, $5 \mathrm{mg} \mathrm{kg}^{-1}$ ); Sunset Y (E 110, $\left.5 \mathrm{mg} \mathrm{kg}^{-1}\right)$; Sorbic A (E 200, $5 \mathrm{mg} \mathrm{kg}^{-1}$ ); Acid R 33 (E 128, $5 \mathrm{mg} \mathrm{kg}^{-}$ 1); Allura R (E 129, $\left.5 \mathrm{mg} \mathrm{kg}^{-1}\right)$; Carmoisine (E 122, $\left.5 \mathrm{mg} \mathrm{kg}^{-1}\right)$; Fast G (FG, $5 \mathrm{mg} \mathrm{kg}^{-1}$ ); Brilliant B (E 133, $5 \mathrm{mg} \mathrm{kg}^{-1}$ ) in yogurt extract using the developed method.

\section{Optimizing the extraction method}

To obtain a simple and efficient multi-detection method for analysis of the twelve studied FA with shortening the sample preparation steps, a mixture of $\mathrm{H}_{2} \mathrm{O}: \mathrm{MeOH}(1: 3)$ was firstly tested for jam and yogurt analyses both with a dilution factor (DF) of 10 and for soda sample of DF 5 . Satisfactory recoveries were 
obtained for soda juice samples for nearly all the studied FA except for Ponceau. On the other hand, lower recoveries were obtained for all the studied artificial colors in jam and yogurt, only acceptable recoveries were obtained for benzoic and sorbic acid.

Based on these results, it was suggested that there is an adsorption interaction between the studied artificial colors and the membrane of the used acrodisc syringe filter, as these colors have high molecular weights (Table I) with planar structures. Such adsorption may be increased in the presence of matrices which may bind with these colors and results in an increment in its adsorption on the membrane of the acrodisc syringe filter used. This adsorption was confirmed by comparing the obtained recoveries when applying this method with and without using acrodisc syringe filter. As shown in Table II, better results were obtained for jam sample in the absence of acrodisc syringe filter. Also, Ponceau's recovery in soda sample was largely improved in the absence of acrodisc syringe filter. In addition, lower recoveries were obtained for all the studied food colors in the soda sample when applying acrodisc syringe filter of $0.20 \mu \mathrm{m}$. On the other side, only slightly enhancement was obtained for the recoveries of the studied food colors in the yogurt sample. This is maybe attributed to the presence of an additional factor concerning the coprecipitation between the studied colors and the precipitated protein.

Table II. Comparison of percentage recoveries (RSD in parentheses) obtained for the analysis of the studied food additives in soda juice, jam, and yogurt using the developed method with and without acrodisc syringe filter of different pore sizes

\begin{tabular}{|c|c|c|c|c|c|c|c|}
\hline \multirow{3}{*}{$\begin{array}{l}\text { Food } \\
\text { Additive }\end{array}$} & \multicolumn{3}{|c|}{ Soda Juice } & \multicolumn{2}{|c|}{ Jam } & \multicolumn{2}{|c|}{ Yogurt } \\
\hline & \multicolumn{2}{|c|}{ Acrodisc SZ of } & \multirow{2}{*}{$\begin{array}{l}\text { Without } \\
\text { filtering }\end{array}$} & \multirow{2}{*}{$\begin{array}{c}\text { Acrodisc } \\
\text { SZ of }\end{array}$} & \multirow{2}{*}{$\begin{array}{l}\text { Without } \\
\text { filtering }\end{array}$} & \multirow{2}{*}{$\begin{array}{c}\begin{array}{c}\text { Acrodisc } \\
\text { SZ of }\end{array} \\
0.4 \mu \mathrm{m}\end{array}$} & \multirow{2}{*}{$\begin{array}{l}\text { Without } \\
\text { filtering }\end{array}$} \\
\hline & $0.4 \mu \mathrm{m}$ & $0.2 \mu \mathrm{m}$ & & & & & \\
\hline Tartrazine & $66(17)$ & 0 & $81(6)$ & 0 & $71(14)$ & 0 & 0 \\
\hline Indigo & $87(2)$ & $27(18)$ & $80(0)$ & 0 & $70(5)$ & $15(15)$ & $46(1)$ \\
\hline Benzoic A & $128(5)$ & $128(9)$ & $108(14)$ & $84(9)$ & $113(0)$ & $129(4)$ & $137(19)$ \\
\hline Sorbic A & $92(3)$ & $83(7)$ & $88(2)$ & $93(4)$ & $91(2)$ & $81(8)$ & $93(3)$ \\
\hline Amaranth & $61(6)$ & 0 & $87(3)$ & 0 & $62(8)$ & 0 & 0 \\
\hline Ponceau & $38(10)$ & 0 & $77(3)$ & 0 & 75 (6) & 0 & $4(15)$ \\
\hline Sunset $Y$ & $79(4)$ & $28(23)$ & $78(3)$ & 0 & $133(17)$ & $28(15)$ & $54(1)$ \\
\hline Acid R 33 & $70(6)$ & 0 & $79(2)$ & 0 & $79(7)$ & 0 & $35(1)$ \\
\hline Allura $\mathrm{R}$ & $78(4)$ & $20(19)$ & $80(0)$ & 0 & $81(6)$ & $25(13)$ & $57(1)$ \\
\hline Carmoisine & $61(7)$ & 0 & $79(0)$ & 0 & $81(5)$ & 0 & $39(3)$ \\
\hline Fast G & $82(4)$ & $47(15)$ & $79(0)$ & 0 & $83(6)$ & $41(7)$ & $54(2)$ \\
\hline Brilliant B & $84(4)$ & $57(11)$ & $80(0)$ & 0 & $82(6)$ & $48(6)$ & $59(1)$ \\
\hline
\end{tabular}

Therefore, the mixture of $\mathrm{H}_{2} \mathrm{O}: \mathrm{MeOH}(1: 3, \mathrm{v}: \mathrm{v})$ was further tested with the addition of $\mathrm{NaOH}$ solution in order to enable the formation of the corresponding soda salts of the studied food additives. The formation of sodium salts of the studied FA (especially food colors) may results in an increment in its solubility with subsequently lowering its adsorption on the membrane of the acrodisc syringe filter $(0.45 \mu \mathrm{m})$. As expected, better recoveries were obtained for all the studied FA when using a mixture of $\mathrm{H}_{2} \mathrm{O}: \mathrm{MeOH}(1: 3$, $\mathrm{v}: \mathrm{v})$ containing 0.01 and $0.03 \mathrm{~mol} \mathrm{~L}^{-1} \mathrm{NaOH}$. Higher concentrations of 0.06 and $0.12 \mathrm{~mol} \mathrm{~L}^{-1}$ of $\mathrm{NaOH}$ have also been tested but it led to degradation of indigo. Finally, the mixture of $\mathrm{H}_{2} \mathrm{O}: \mathrm{MeOH}(1: 3, \mathrm{v}: \mathrm{v})$ containing 
$0.01 \mathrm{~mol} \mathrm{~L}^{-1} \mathrm{NaOH}$ was selected for all the tested samples as it doesn't lead to degradation for indigo even after $24 \mathrm{~h}$. Therefore, this extraction solution was further full validated in all the studied matrices and used for the analysis of different real samples.

\section{Method validation}

As presented in Table III, most of the studied FA has acceptable recoveries at range $60-100 \%$ with RSDs $\leq 20 \%$ at all the studied concentration levels, which is in agreement with the European guidance document on quality control and method validation for pesticides residues analysis in food and feed (SANTE/11813/2017). Also, acceptable results were obtained for the inter-day measurements, listed in Table IV. The coefficient of determination $\left(r^{2}\right)$ for each of the studied FA was calculated by plotting signal responses against its expected concentration. As presented in Tables IV, $r^{2}$ for each studied FA, in the three studied matrices, was $\geq 0.9960$, indicating excellent linearity for the analyzed FA using the developed method.

Table III. Percentage recoveries (Rec) and relative standard deviation (RSD) at three concentration levels of $0.50,1.25$, and $2.50 \mathrm{mg} \mathrm{kg}^{-1}$ for all the studied FA except for tartrazine and benzoic acid at 1.00, 2.50, and $5.00 \mathrm{mg} \mathrm{kg}^{-1}$ in soda juice (dilution factor of 5), with Rec and RSD at twofold values in Jam and yogurt (dilution factor of 10$), n=5$ in the same day

\begin{tabular}{|c|c|c|c|c|c|c|c|c|c|}
\hline \multirow{3}{*}{$\begin{array}{l}\text { Food } \\
\text { Additivies }\end{array}$} & \multicolumn{3}{|c|}{ Soda Juice } & \multicolumn{3}{|c|}{ Jam } & \multicolumn{3}{|c|}{ Yogurt } \\
\hline & L1 & L2 & L3 & L1 & L2 & L3 & L1 & L2 & L3 \\
\hline & $\begin{array}{l}\text { Recl } \\
\text { RSD }\end{array}$ & $\begin{array}{l}\text { Recl } \\
\text { RSD }\end{array}$ & $\begin{array}{l}\text { Rec/ } \\
\text { RSD }\end{array}$ & $\begin{array}{l}\text { Recl } \\
\text { RSD }\end{array}$ & $\begin{array}{l}\text { Rec/ } \\
\text { RSD }\end{array}$ & $\begin{array}{l}\text { Rec/ } \\
\text { RSD }\end{array}$ & $\begin{array}{l}\text { Rec/ } \\
\text { RSD }\end{array}$ & $\begin{array}{l}\text { Rec/ } \\
\text { RSD }\end{array}$ & $\begin{array}{l}\text { Recl } \\
\text { RSD }\end{array}$ \\
\hline Tartrazine & $<\mathrm{LOQ}$ & $68(4)$ & $80(3)$ & $<\mathrm{LOQ}$ & $121(3)$ & $81(2)$ & $<L O Q$ & $82(10)$ & $82(9)$ \\
\hline Indigo & $85(27)$ & $100(6)$ & $90(6)$ & $81(9)$ & $82(21)$ & $102(9)$ & $56(9)$ & $83(5)$ & $85(2)$ \\
\hline Benzoic A & $<\mathrm{LOQ}$ & $105(1)$ & $96(2)$ & $<\mathrm{LOQ}$ & $133(5)$ & $98(1)$ & $<\mathrm{LOQ}$ & $<\mathrm{LOQ}$ & $106(18)$ \\
\hline Sorbic A & $80(9)$ & $101(4)$ & $97(3)$ & $99(11)$ & $97(11)$ & $98(2)$ & $82(4)$ & $86(15)$ & $88(2)$ \\
\hline Amaranth & $69(25)$ & $81(10)$ & $79(4)$ & $98(16)$ & $86(5)$ & $87(3)$ & $87(7)$ & $92(2)$ & $78(11)$ \\
\hline Ponceau & $68(17)$ & $87(5)$ & $89(4)$ & $93(8)$ & $92(5)$ & $88(2)$ & $78(3)$ & $79(3)$ & $86(2)$ \\
\hline Sunset $Y$ & $75(18)$ & $96(4)$ & $95(1)$ & $78(17)$ & $81(24)$ & $92(8)$ & $78(16)$ & $80(2)$ & $87(2)$ \\
\hline Acid R 33 & $74(10)$ & $96(4)$ & $93(1)$ & $84(10)$ & $88(7)$ & $93(2)$ & $78(7)$ & $86(4)$ & $88(1)$ \\
\hline Allura R & $76(15)$ & $99(3)$ & $96(2)$ & $93(8)$ & $89(6)$ & $96(1)$ & $91(9)$ & $87(3)$ & $87(2)$ \\
\hline Carmoisine & $67(17)$ & $90(7)$ & $90(3)$ & $90(10)$ & $90(6)$ & $89(1)$ & $75(7)$ & $88(3)$ & $89(1)$ \\
\hline Fast G & $83(14)$ & $102(2)$ & $97(1)$ & $90(6)$ & $90(5)$ & $95(0)$ & $87(4)$ & $87(3)$ & $89(1)$ \\
\hline Brilliant B & $84(11)$ & $100(3)$ & $93(2)$ & $94(5)$ & $93(5)$ & $100(1)$ & $89(2)$ & $87(3)$ & $89(1)$ \\
\hline
\end{tabular}

LOQ: Limit of quantification 
Table IV. Recoveries (Rec) and relative standard deviation (RSD) at concentration levels of $2.50 \mathrm{mg} \mathrm{kg}^{-1}$ for all the studied FA except for tartrazine and benzoic acid at $5.00 \mathrm{mg} \mathrm{kg}^{-1}$ in soda juice (dilution factor of 5), with Rec and RSD at twofold values in jam and yogurt (dilution factor of 10 ), $n=5$ in five replicate days, with the calculated coefficient of determination $\left(r^{2}\right)$

\begin{tabular}{|c|c|c|c|c|c|c|}
\hline \multirow{2}{*}{$\begin{array}{l}\text { Food } \\
\text { Additivies }\end{array}$} & \multicolumn{2}{|c|}{ Soda juice } & \multicolumn{2}{|c|}{ Jam } & \multicolumn{2}{|c|}{ Yogurt } \\
\hline & Rec/RSD & $r^{2}$ & Rec/RSD & $r^{2}$ & Rec/RSD & $r^{2}$ \\
\hline Tartrazine & $100(19)$ & 0.99961 & $81(5)$ & 0.996036 & $103(8)$ & 0.99869 \\
\hline Indigo & $99(14)$ & 0.99947 & $94(7)$ & 0.999936 & $96(4)$ & 0.996481 \\
\hline Benzoic A & $98(22)$ & 0.99740 & $97(9)$ & 0.99878 & $114(20)$ & 0.999424 \\
\hline Sorbic A & $101(5)$ & 0.99993 & $98(9)$ & 0.999884 & $88(5)$ & 0.999957 \\
\hline Amaranth & $84(16)$ & 0.99964 & $87(6)$ & 0.998702 & $75(9)$ & 0.999859 \\
\hline Ponceau & $93(9)$ & 0.99989 & $88(3)$ & 0.999756 & $76(22)$ & 0.999917 \\
\hline Sunset $Y$ & $96(4)$ & 0.99986 & $92(8)$ & 0.999745 & $89(3)$ & 0.999986 \\
\hline Acid R 33 & $98(5)$ & 0.99984 & $94(3)$ & 0.999835 & $87(6)$ & 0.999983 \\
\hline Allura R & $99(4)$ & 0.99982 & $96(2)$ & 0.999728 & $92(5)$ & 0.999981 \\
\hline Carmoisine & $93(6)$ & 0.99974 & $89(3)$ & 0.999816 & $82(18)$ & 0.999975 \\
\hline Fast G & $99(3)$ & 0.99981 & $95(2)$ & 0.999779 & $92(4)$ & 0.99999 \\
\hline Brilliant B & $99(3)$ & 0.99985 & $100(2)$ & 0.999771 & $96(4)$ & 0.999963 \\
\hline
\end{tabular}

The lowest validation concentration levels studied (Table III) were considered as the limit of quantification of the developed method for most of the studied FA, according to the SANTE/11813/2017. Only tartrazine and benzoic acid have a higher limit of quantification in all the studied commodities. The LOQ for tartrazine analysis in jam and yogurt equals to $5.00 \mathrm{mg} \mathrm{kg}^{-1}$ and in soda juice equals $2.50 \mathrm{mg} \mathrm{kg}^{-1}$. While, LOQ for benzoic acid analysis using the developed method in soda, jam, and yogurt equals 2.50, 5.00, and 10.00 $\mathrm{mg} \mathrm{Kg}{ }^{-1}$. However, these LOQs are lower than previously reported LOQs in a method applied using LC$\mathrm{MS} / \mathrm{MS}$ for food color analysis in species samples [9]. Although this study reported an extraction method using a complex mixture of solvents $\left(\mathrm{H}_{2} \mathrm{O} / \mathrm{MeOH} / \mathrm{ACN} / \mathrm{THF}, 9: 1: 5: 5, \mathrm{v} / \mathrm{v} / \mathrm{v} / \mathrm{v}\right)$ and carried out longer stirring extraction time of $30 \mathrm{~min}$, the reported LOQs for tartrazine, amaranth, and ponceau analysis are 10, 3.00, $2.00, \mathrm{mg} \mathrm{kg}^{-1}$. These LOQs higher than that obtained in the current study (in all the studied matrices) may be attributed to the acrodisc syringe filter of $0.20 \mu \mathrm{m}$ used without the $\mathrm{NaOH}$ additive in the extract solution. However, Waleska et al. [16] have reported lower LOQs for the analysis of 10 artificial colors in yogurt. This study reported repeated extraction steps using methanol: ammonium hydroxide $\left(2 \mathrm{~mol} \mathrm{~L}^{-1}\right)(80: 20)$ after protein precipitation using $\mathrm{K}_{4} \mathrm{Fe}(\mathrm{CN})_{6} 3 \mathrm{H}_{2} \mathrm{O}\left(0.35 \mathrm{~mol} \mathrm{~L}^{-1}\right)$ and $0.5 \mathrm{~mL} \mathrm{ZnSO}{ }_{4} 7 \mathrm{H}_{2} \mathrm{O}\left(1 \mathrm{~mol} \mathrm{~L}^{-1}\right)$. This study confirms our suggestion about the importance of adding basic additives to the extract solution to enhance the recoveries of the tested food colors. However, this study didn't discuss the importance of such basic additives in minimizing adsorption of tested colors on the membrane of the used acrodisc syringe filter. Besides, it involves many preparation steps. A previously reported method [18] also used $\mathrm{NaOH}$ just to neutralize the soda solution (as mentioned by the authors) for the analysis of allura red and ponceau with LOQ of $0.30 \mathrm{mg} \mathrm{L}^{-1}$ without discussing its rule in lowering the adsorption of tested food colors in the membrane of the acrodisc syringe filter as investigated in the current study, especially for ponceau in soda sample. While nearly all the studied food colors cannot be analyzed in jam and yogurt without adding $\mathrm{NaOH}$ to the extract solution. 


\section{Analysis of real samples}

The validated method was applied for the analysis of eighteen real samples, including eight soda juices, five jams, and five yogurt samples, all of which were purchased from local markets in Oman. The obtained results for these analyses are presented in Table V. As can be seen, soda samples were the most susceptible samples containing one or more food additives. Most of the soda samples were containing benzoic and or sorbic acid together with at least one food color. These results confirm the importance of our developed method that simultaneously enables the analysis of FA with food colors. There is one jam sample containing sunset yellow and another one containing a high concentration of benzoic acid of 767 $\mathrm{mg} \mathrm{kg}^{-1}$, exceeding its EU maximum permissible limits. On the other hand, no food colors were found in the collected yogurt samples, with the presence of only low concentrations of benzoic acid.

Table V. Levels of the detected food additives and its concentrations in the analyzed real samples

\begin{tabular}{|c|c|c|c|c|}
\hline Sample & $\mathrm{N}^{\circ}$ of sample & Food Additive & $\mathrm{N}^{\circ}$ of detection & Range min-max $\left(\mathrm{mg} \mathrm{kg}^{-1}\right)$ \\
\hline \multirow{3}{*}{ Soda Juice } & \multirow{3}{*}{8} & Tartrazine & 2 & $5.4-8.7$ \\
\hline & & Benzoic Acid & 6 & $83.25-181$ \\
\hline & & Sorbic Acid & 6 & $0.50-173$ \\
\hline \multirow{3}{*}{ Jam } & \multirow{3}{*}{5} & Benzoic & 1 & 767 \\
\hline & & Sorbic Acid & 1 & 2 \\
\hline & & Sunset $Y$ & 1 & 4.3 \\
\hline Yogurt & 5 & Benzoic Acid & 3 & $1.5-4.65$ \\
\hline
\end{tabular}

\section{CONCLUSION}

In the current study, a complete liquid chromatography separation for eluted peaks of 10 food colors together with 2 food additives was achieved at a run time of $22 \mathrm{~min}$. The addition of $\mathrm{NaOH}$ to the used extraction solution is a highly advantageous approach for the determination of different food colors simultaneously with food preservatives. A mixture of $\mathrm{H}_{2} \mathrm{O}: \mathrm{MeOH}$ containing $0.01 \mathrm{~mol} \mathrm{~L}^{-1} \mathrm{NaOH}$ largely decreases the adsorption of the analyzed food colors in the membrane of the acrodisc syringe filter of 0.45 $\mu \mathrm{m}$ used. In addition, it enables proper extraction of the tested food additives in the high protein contents samples, like yogurt. The developed method was fully validated in three sample matrices include soda, jam, and yogurt. Analysis of real samples using the developed method indicates the presence of more than one food color together with one or two food preservatives at elevated concentrations, especially in the analyzed soda samples.

\section{REFERENCES}

1. Tsai, C.; Kuo, C.; Shih, D. Y. J. Food Drug Anal., 2015, 23, pp 453-462.

2. Kucharska, M.; Grabka, J. Talanta, 2010, 80, pp 1045-1051.

3. Yamjala, K.; Subramania, M.; Rao, N. Food Chem., 2016, 192, pp 813-824.

4. Balakrishnan, V. K.; Shirin, S.; Aman, A. M.; De Solla, S. R.; Mathieu-denoncourt, J.; Langlois, V. S. Chemosphere, 2016, 146, pp 206-215.

5. Shimadzu Application News. Fast and High Sensitivity Analysis of Six Preservatives in Beverages by UHPLC with Photodiode Array Detection, Application No: AD-0095.

6. Timofeeva, I.; Kanashina, D.; Stepanova, K.; Bulatov, A. J. Chromatogr. A., 2019, 1588, pp 1-7.

7. Tfouni, S. A. V.; Toledo, M. C. F. Food Control, 2002, 13, pp 117-123.

8. Martin, F.; Oberson, J.; Meschiari, M.; Munari, C. Food Chem., 2016, 197, pp 1249-1255. 
9. Périat, A.; Bieri, S.; Mottier, N. Food Chemistry: X, 2019, 1, 100009 (https://doi.org/10.1016/j. fochx.2019.100009).

10. Li, X. Q.; Zhang, Q. H.; Ma, K.; Li, H. M.; Guo, Z. Food Chem., 2015, 182, pp 316-326.

11. Karanikolopoulos, G.; Gerakis, A.; Papadopoulou, K.; Mastrantoni, I. Food Chem., 2015, 177, pp 197-203.

12. Vani, F.; Andrade, D.; Izabel, M.; Guedes, F.; Gusmão, Í.; Vieira, P.; Noélia, F.; Mendes, P.; Alves, P.; Rodrigues, S.; et al. Food Chem., 2014, 157, pp 193-198.

13. Sirhan, A. Y.; Bola, L.; Mostafa, A.; Talhouni, A.; Al-ebini, Y. Int. J. Appl. Eng. Res., 2018, 13, pp 4693-4701.

14. Bonan, S.; Fedrizzi, G.; Menotta, S.; Elisabetta, C. Dyes Pigm., 2013, 99, pp 36-40.

15. Sobanska, A.; Pyzowski, J. Acta Innovations, 2018, 27, pp 53-60.

16. De Araújo, W.; Bento, S.; Parente, B.; Paula, A.; Paim, S. Anal. Methods, 2015, 183, pp 154-160.

17. European Commission. SANTE/11813/2017. Guidance document on analytical quality control and method validation procedures for pesticide residues and analysis in food and feed. Implemented by 01/01/2018.

18. Jurcovan, M. M.; Diacu, E. Rev. Chim., 2014, 65, pp 137-141. 